\title{
Temel Grafik Eğitiminde Tasarım Elemanları ile Görsel Algı Oluşturma: 2. Sınıf Temel Grafik Eğitimi Dersi Proje Örneği
}

Özet

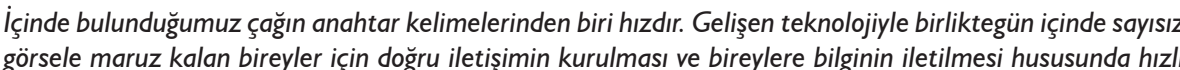
görsele maruz kalan bireyler için doğru iletişiminin kurulması ve bireylere bilginin iletilmesi hususunda hızl
bir ayırt edicilik yakalamak önemli bir rol edinir. Verilmek istenen mesajin iletilmesi ve izleyici tarafindan bir ayırt edicilik yakalamak önemli bir rol edinir. Verilmek istenen mesajın iletilmesi ve izleyici tarafindan anlamlandırılması noktasında da grafik tasarımcılar devreye girmektedir. Bir grafik ürünün başarısı da görsel algı ve bütünlük oluşturmak önemlidir. Tasarımcı, bir grafik tasarım ürününün görsel dilini tasarım elemanları ve tasarım prensipleri kullanarak kurgular. Tüm bu prensiplerin ortak amacı verilmek istenen mesajın iletilmesi konusunda yardımcı olmaktır. Iletişim sorunlarııı çözecek görsel çözümler sunulması iletişim tasarımın birincil amaç̧larındandır. Doğru iletişimi kurması için eğitilen tasarımcı adaylarının alacağı

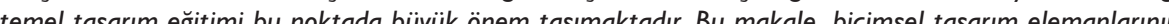
etkin kullanimi ile gorsel algi oluscur etkin kullanm Sanatlar Fakültesi Grafik Bölümü mürredatında olan Temel Grafik Eğitimi dersi kapsamında verilen tasarım elemanları ve prensiplerinin aşamalı ve uygulamalı anlatımının proje örneğini açıklamaktadır.

Anahtar Kelimler: Tasarım Eğitimi, Tasarım Elemanları, Görsel Algı, Grafik Tasarım Eğitimi

CREATING VISUAL PERCEPTION USING DESIGN ELEMENTS IN BASIC GRAPHIC DESIGN EDUCATION: A SAMPLE OF 2ND GRADE BASIC GRAPHIC DESIGN STUDIO PROJECT

\section{Abstract}

One of the key words of our age is speed. As we are exposed to countless visuals during the day, quickly establishing correct ways of communication is becoming increasingly important. Graphic designers come into play at the point of correctly conveying the message to be perceived by the audience. The success of a graphic product can also be measured by how quickly and correctly it can deliver the message to the target audience in the most effective way. In order for the message to be understandable, it is important to create right visual perception. The designer builds the visual language of a design product mainly using basic design elements and design principles. Providing visual solutions to solve communication problems is one of the primary gols of commuication design. Therefore, getting the basic design educotion course for of designer can idates whe importance. This aricle explans a project sample of the practical explation principles given within the Basic Graphic Design Education course in Hacettepe University Faculty of Fine Arts Graphics Department curriculum.

Keywords: Design Education, Design Elements, Visual Perception, Graphic Design Education 


\section{Giriş}

Görsel iletişimin ve görsel okuryazarlığın temelleri insanlık tarihi ile birlikte başlamıștır. Mağara duvarlarına yapılan resimler görsel yolla anlatımın ilk örneklerini oluşturmuştur. Uçar, Orhon, Taş̧̧ığlu ve Kılıç, görsel iletişimi kısaca "görsel öğeler kullanarak mesaj yollama ve alma süreci" olarak tanımlar (2013). Duvar resimleri ile başlayan süreç aynı zamandapetroglif1, jeoglif ${ }^{2}$, çivi yazısı ve hiyeroglifler gibi farklı piktogram ve ideogramlar oluşturarak görsel birer iletissim aracı olarak gelişmiş̧ir. Son olarak hiyeroglifler ikonikten fonetik alfabeye geçiş olan Fenike alfabesinin temelini oluşturarak modern alfabe sisteminin başlangııını belirlemiştir (Heller, 2015:192).Sese dayalı fonetik alfabenin gelişmesi ile birlikte dilsel iletişim gelişmiş ve iletişimimizin birincil basamağını oluşturmuş olsa da, görsel öğelerden anlam üretme yetisi olan görsel okuryazarlık önemini hiçbir zaman kaybetmemiştir. Uçar, yirminci yüzyıldan itibaren başlayan tarihsel süreci görsel çağ olarak adlandırmaktadır. Yapılan araştırmalar insan beyninin maruz kaldığı bilginin yüzde 75 'inden fazlasının görsel iletişim yolları ile oluştuğunu ortaya koymaktadır (Uçar vd., 2013:143). Görseller ve imgeler üzerinden bir anlam yaratma, yansıtma ve eleștirme görevi de temel olarak tasarımcılardadır. Görsel mesajların bulunduğu bir mecra veya sistem üzerinden izleyiciye çözümleyebileceği, anlamlandırabileceği ve 'okuyabileceği' bir kaynak oluştururlar. Günümüzde iletişim kaynaklarının ve mecralarının gelişen teknoloji ile her geçen gün artmasıyla birlikteiletisim yollarının da sekillerinin de profesyoneller tarafından tasarlanması ve alıııya uygun mesajı verecek şekilde düzenlenmesi gerekmektedir. Bu noktada bu görsel iletişim kanalını inşa edecek kişi de grafik tasarımcıdır. İletişim kanallarının çoğalması, disiplinler arası geçirgenliğin artması ve çok platformlu içerik intiyacının ortaya çıkmasıyla birlikte grafik tasarım terimi de bu mesleği yeterli ölçüde tanımlamamaktadır. 2007 yılında La Habana' da düzenlenen Icograda Genel Kurulu tarafından "Grafik tasarım" yerine "iletişim tasarım" teriminin kullanılması uygun bulunmuştur. Iletişim tasarım, "temel olarak iletişim sorunlarına görsel çözümler sağlamaya dayalıdır." (Icograda, 2011:8)3. Illetişim problemlerini çözecek doğru görsel çözümlerin yaratılması ise ancak sanat ve tasarım eğitimi ile gerçekleşebilir. Temel tasarım eğitiminin ders olarak okullara girmesi modernizm dönemi Bauhaus ekolüne dayanmaktadır(Steven, 2005:5). William Morris gibi

'Petroglif: kaya üzerine çizilen ikonik işaretler. Bkz. https://www.nps.gov/petr/learn/historyculture/what htm (Erişim Tarihi: 02 Kasım 2020)

${ }_{2}^{2}$ Jeoglif: geniş bir arazi üzerine çizilen ve kuş bakışı görülebilecek olan büyük çizimler. Bkz. https://link.

springer.com/referenceworkentry/I 0. 1007\%2F978-I-44/ 9-0465-2_1625 (Erişim Tarihi I8 Ekim 2020)

${ }_{3}^{3}$ Manifestonun tam metni için bkz. https://www.ico-d.org/database/files/library/

IcogradaEducationManifesto_201 I.pdf (Erişim Tarihi 10 Ekim 2020). el sanatlarının makineleşmeyleiyileştirilemeyeceğini düşünen ve zanaatın teknolojiden ayrı tutulması gerektiğini savunan sanatçılara karşın; Bauhaus okulu makineleşmenin faydalarının ve kolaylıklarını ve bunu sanat ve tasarımla birleştirmeyi düşünen Walter Gropius tarafından 1919 yılında Weimar'da kurulmuştur. (Bektaş, 1992: 69). Bauhaus, sadece eğitim kurumu olarak değil, aynı zamanda bir araştırma, inceleme, uygulama ve bir tartışma yeri olma özelliği taşımıştır (Meggs, 2012: 328). Okulun eğitim modelinin temellerinden birini oluşturan temel sanat eğitimi ve temel tasarım dersleri günümüzde halen ulusal ve uluslararası birçok sanat eğitimi veren okulun müfredatında bulunmaktadır. Bugünakademilerin çoğunluğu Bauhaus ekolünü eğitim modelleri olarak kabul etmiş ve müfredatlarını bu sistemin üzerine kurmuştur (Wingler, 1979). Moholy Nagy tasarımın sadece bir uzmanlık alanı değil aynı zamanda bir görüş şekli ve bir yaklaşım olduğunu savunmuştur (Findeli, 2001: 16). Bu görüşe uygun olarak Bauhaus okulu da eğitim sistemini hiçbir zaman sadece bir uzmanlık alanı gibi düşünmemiş, tasarımı bir tutum ve bakış açısı olarak algılamıştır. El becerileri ve temel tasarım eğitimi her zaman tasarım eğitiminde önemli olmuştur ve olacaktır (Findeli, 2001:16). Bauhaus ekolünün başlatmış olduğu bazı temel tasarım ilkelerinin günümüzde halen geçerli olduğu görülmektedir. "Tasarıma giriş eğitimi" olarak da adlandırılan bu eğitim, tasarımcı adayları için ilk adımdır. Bu bağlamda farkındalık yaratma, görsel duyarlılık kazanma, soru ve çözümlerin nasıl çeşitlendirilebileceğini anlama becerileri bu aşamada edinilmesi gereken önemli unsurlardır.

Temel Tasarım Eğitimi ${ }^{4}$, temelinde tasarımcı görüsünü geliştirme pratiğini içermektedir. İçerik, kapsam, amaç ve planlama bu eğitimin temelini oluşturmaktadır. Ders kapsamında yaratıcı düşünme süreci, duyguları ve mesajları organize etme, sistematik ve işlevsel duyarlılık, görsel farkındalık, eleştirel düşünmenin ve yaratma cesaretinin sağlanması gibi önemli hususlar üzerinde durulmakta ve bu kavramların pekiştirilmesi için çalışmalar yapılmaktadır. Hacettepe Üniversitesi Güzel Sanatlar Fakültesi Grafik Bölümü'nde Temel Tasarım Eğitimi dersinin devam niteliğinde 2. Sınıflara verilen Temel Grafik Eğitimi dersi bilgi paketine göre;

Çizgi ve düzlemleri kullanarak üçüncü boyut yaratmayı öğrenir ve bu boyutlandırma tekniğini grafik ögeler yaratmak için kullanabilir.

Täriki Güzel Sanatlar Yüksek Okulu'nda verilmeye başlanmıştır (Marmara Üniversitesi, 20I3). Hacettepe Üniversitesi Güzel Sanatlar Fakültesi'nde ise 1983 yllında Güzel Sanatlar Fakültesi' nin kurulmasılyla birlikte Temel Tasarım Eğitimi dersi verilmeye başlanmıştır. Tüm dünyada olduğu gibi ülkemizde de lisans seviyesinde tasarım ve güzel sanatlar fakültelerinde, yüksekokullarda ve meslek okullarında bu ders en temel tasarıma giriş dersi olarak okutulmaktadır. Bkz. http://tem.gsf.marmara.edu.tr/genel-bilgiler (Erişim Tarihi I0 Ekim 2020). 
Tipografik elemanları kullanarak soyut kavramları grafik nesnelere ve görselliğe dönüştürebilir ve böylece ilk temel grafik tasarım çalışmasını ortaya koyar.

Aynı görsel elemanları erken düzey renklendirme çalışmalarıyla farklı anlamlar yaratacak şekilde düzenleyebilir ${ }^{5}$

\section{Çalışmanın Amacı}

Bu çalışma, biçimsel tasarım elemanlarının etkin kullanımı ile görsel algı oluşturmanın önemini öğretmek amacıyla, Hacettepe Üniversitesi Güzel Sanatlar Fakültesi Grafik Bölümü müfredatında olan 2019-2020 eğitim dönemi Temel Grafik Eğitimi I ve II dersi kapsamında verilen tasarım elemanları ve prensiplerinin aşamalı ve uygulamalı anlatımının proje örneğini açıklamaktadır.

\section{Çalışmanın Kapsam ve Yöntemi}

Örnekte incelenen proje her sene düzenli olarak Hacettepe Üniversitesi Güzel Sanatlar Fakültesi Grafik Bölümü Temel Grafik Eğitimi dersi kapsamında her sene çalışlıyor olsa da bu çalıșmanın kapsamı, 2019-2020 eğitim öğretim döneminde Temel Grafik Eğitimi I ve II dersinialan öğrencilerin çalışma örnekleriyle sınırlandırılmıştır.Bu çalışmada yöntem olarak ise tarama yöntemi ve örnek olay incelemesi tekniklerinden faydalanılmıștır. Amaca yönelik geliştirilen ders içeriği ile öğrencilerin gelişimi gözlemlenmiştir.

\section{Tasarım Elemanları ve Görsel Algı Arasındaki ilişski}

Grafik tasarımda görsel üretimi, araç ve amaç fark etmeksizin, biçimsel elemanların manipülasyonlarından üretilen görseller üzerine kuruludur. Biçim; sekil, çizgi, örüntü, kelimeler ve görsellerden olusabilir. Tasarımda kullanılan biçim ise ne kadar soyut veya yalın olursa olsun bir anlam taşıyabileceği göz önünde bulundurularak dikkatli ve yerinde kullanılmalıdı (Rand, 2014:4). Biçim, tasarımda mesajı ileten bir araç görevi görmektedir. İnsan beyni biçimleri okuyup önceden oluşturduğu kodlarla birleştirmeye ve bir anlam çıkarmaya meyillidir. Buna görsel okuryazarlık denmektedir. Uçar, Orhon, Taşçıŏlu ve Kılıç'ın "Görsel Kültür" kitap çalışmasında bir bireyin görsel okuryazar olabilmesi için yapması gereken temel değerlendirmeleri aşağıdaki şekilde sıralamışlardır: 5 Hacettepe Üniversitesi Grafik Bölümü Temel Grafik Eğitimi I bilgi paketi için bkz. http://akts.hacettepe
edu.tr/ders_detay.php?ders_ref=DRSTNM_000000000000000000000720\&ders_kod=GRA233\&zs_ link $=$ I \&prg_kod =462\&submenuheader $=2$ (Erişim Tarihi I 2 Ekim 2020).
- Görsel parça veya bütünlerin konusunu anlayabilmeli,

- Görsel parça veya bütünlerin içinde bulundukları kültürel yapıda kazandıkları ve sahip oldukları anlamı anlayıp yorumlayabilmeli,

- Görsel parça veya bütünlerin stil ve düzenini görsel yapı açısından değerlendirebilmeli,

- Görsel parça veya bütünlerin üretilmesinde kullanılan teknikleri inceleyebilmeli,

- Görsel çalışmanın estetik değerini değerlendirebilmeli,

- Görsel çalışmanın değerini, amacı ve hedef kitlesi açısından değerlendirebilmeli,

- Görsel öğe veya bütünün ortaya koyduğu topyekün sinerjiyi, etkileşimi, yeniliği, etkin yanını ve hissettirdiklerini de tartışabilmel (Uçar vd., 2013:147)

Şekil olarak kullanılmış bir daire, kişide içeriğe göre 'top, güneş, ay, madeni para, altın,vb. gibi anlamlar taşıyabilir. Bu sebeple doğru mesajı iletmek için doğru biçimin kullanııması esastır.Biçimler oluştuğunda ise alan oluşur. Burada bahsedilen alan genellikle 2 boyutluyüzeylerdir. Bu alan bir afiş, web sayfası, kartvizit, billboard veya bir vitrin olabilir. TDK'ye göre alan; 'düz, açık ve genis yer, meydan, saha' anlamına gelmektedir. Burada bahsedilecek olan alan ise tasarımda genellikle bir yüzeyin biçimler oluştuktan sonra ortaya çıkan bir yerdir.Biçimlerin çeşitli alanlar üzerinde oluşması ile de algı süreci başlatılmıs olur.Tasarımcı yaratıcı süreç sonunda bir algı yaratır ve algının yönlendirilmesini sağlayacak güce sahiptir. Tasarımda algıyı yönlendirmek ve istenilen sekilde olusturmak bu noktada önemli bir ro edinir. Algı duyu organları aracılığı ile bireyin çevresinde gözlemlediği verilerin tümüdür. Algılanan ise, nesnelerin birey tarafından görünen, kabul edilen gerçekliğidir. Görsel algı ise kişinin çevresini ve çevredeki objeleri ışığın yansımaları sayesinde algılaması ve bu bilgileri yorumlama becerisidir (Arnheim, 2009: 36).

İsviçreli dilbilimci, göstergebilimci ve filozof Ferdinand de Saussure'e göre algılama süreci içinde fiziksel etkenler (kokular, tatlar, görüntüler, sesler vb....) dışında, birey kendi deneyimlerinden ve yaşantısından da yararlanmaktadır. Bu doğrultuda da algıladığı nesneyi yorumlamakta, ona anlamlar yüklemektedir. Bu yönüyle "algı" öznel bir yapıya sahiptir. Güz, Huner, Senemoğlu ve Öztokat (2002) çalışmalarında kültürel farklılıklar ve kolektif bilincin algıyı yönlendirebildiğini öne sürmektedirler. Arnheim 
da benzer şekilde şekillerin ve renklerin kavranabilirliğinin türlere, kültürel gruplara, gözlemcinin eğitimine bağlı olarak değiştiğini gösteren kanıtlar bulunduğunu ileri sürmektedir. Bir grup için rasyonel olan şey, bir başkası için irrasyonel, yani kavranamaz, anlaşılamaz, karşılaştııllamaz ya da hatırlanamaz olabilir (2009:47). Bu durumda bir tasarımcının da her koşulda içinde bulduğu bölgenin, zümrenin veya coğrafyanın görsel kültürü ve kolektif bilincini dikkate alarak tasarımını kurgulaması doğru olacaktır. Çünkü göstergelerin anlamları farklı kültürlere göre değişkenlik gösterebilir ve tasarımcı bunları bilmekle yükümlüdür. Örneğin renk anlamlarının kültürlere göre değişmesi veya bazı jest ve mimiklerin kullanım alanlarının değişebilmesi gibi. Araba kullanmayı bilen bir insan için R, D, M gibi harfler sadece alfabenin içindeki harflerden birkaçı değildir, bu harfler bir arabada okunduğu zaman başka bir göstergeye Geri (Reverse), Sürüş modu(Drive), Manüel(Manuel) anlamına geleceği sembollere dönüşür. Bu sembollerin kullanımı sürücü olmayanları hedef kitle dışında bırakmaktadır (2009:47). Dolaysıyla eğitimin ve kültürün görsel algıyı şekillendirdiği ve görsel okumanın sonuçlarını değiştirdiği sonucuna varılabilir. Hedef kitle araştırması ve derinlemesine analizi süreci bir tasarımcının izlemesi gereken ilk araştırma alanlarından birisidir. Arnheim'e göre, görsel algı sadece uyaranlar sonucu gözde oluşan bir faaliyet değildir (2009). Görsel algıda zihin etkin bir görev almaktadır. Diğer bir deyişle algı zihnin kavrama boyutlarına göre farklılık gösterebilir. Bu sebeple tasarımcının da hedef kitleyi iyi tanıması ve onlara hitap edecek görsel algıyı kurgulaması önem taşımaktadır.

Insan gözü ve beyni, birlik içinde olan şekilleri tek başlarına oldukları zamandan daha farkıı algılamaktadır. Bütünün anlamı tek tek parçaların taşıdığı anlamdan daha farklı olabilmektedir. İnsan gözünün şekil ve formları nasıl algıladığı üzerine kurulmuş Gestaltteorisii ${ }^{6}$ ilkeleri tasarım alanında sıklıkla kullanılmaktadır (Arnston, 2011:20-21). Görsel algı ve zeka arasında bir ilişki vardır.Insan zekası etkin seçicilik yaparak çevredeki değişimleri fark eder ve bunları bir önem sırasına koyar (Arnheim,2009:36). Görme hareketsizliklerden ziyade değişimler ile ortaya çıkmaktadır. "bir şey ortaya çıktığında ya da gözden kaybolduğunda, bir yerden bir başka yere hareket ettiğinde, şeklini, büyüklüğünü, rengini ya da parlaklığını değiştirdiğinde..." gözleyen kişinin de koşullarının değişeceğini ve algısının belli bir yönde ilerleyeceğini söylemektedir.

${ }^{6}$ Gestalt kuramı Wertheimer, Koffka ve Köhler tarafından oluşturulmuştur. Gestalt kuramının temelinde bütünlük ve birlik vardır, birbirinden bağımsız olan öğeleri psikolojik bir süreç sonucu bütünü oluşturacak şekilde gruplandırma eğilimi olarak açıklanabilir. Bütünün içerisinde bulunan öğelerin ayrı çözümlenmesi ve algılanması değil, öğelerin birbiriyle olan ilişkilerine dayanan birlikteliklerinin nasıl algılandığı ile ilgilidir (Ellis, 1950).
Arnheim için bir değişkenin olmadığı yerde algı da kısıtlanır (2009: 36). Buradan yola çıkarak görsel algının belirli uyaranlar içeren ve bir hareket veya durağanlığı kıracak bir değişimle oluştuğu sonucuna varılabilir. Dolayısıyla, hareket, renk, büyük/küçüklük, şekil, ısıı gölge gibi kavramların görsel algıdaki yerinin yadsınamaz derecede önemli olduğu ve tasarım prensipleriyle neredeyse birebir örtüştüğü söylenebilir. Bir tasarım öğrencisinin karşı tarafa bir mesaj iletirken önem sıralamasına göre oluşturulmuş bir görsel hiyerarşik düzenek kurması ve bunu nasıl yapacağııın pratiğini yapması büyük bir önem taşımaktadır.

Modernist grafik tasarımcı Paul Rand, gereksiz ve konuyla ilgisiz ögelerin olduğu bir grafik tasarımın iyi bir tasarım olmadığını savunmaktadır. Rand'e göre bir eser, biçimsel olarak tasarım ilkelerine uysa veya estetik açıdan hoş olsa bile doğru iletişimi kuramıyor ve amaca hizmet etmekte başarıı olamıyorsa iyi bir tasarım değildir. Rand, tasarımcıların 3 farklı parça ile çalışmaları gerektiğinden bahsetmiştir. Bu üç tür materyal şunlardır:

1. Verilen malzeme: ürün, kopya, slogan, logo, format, medya, üretim süreci;

2. Biçimsel malzeme: boşluk, kontrast, oran, uyum, ritim, tekrar, çizgi, kütle, şekil, renk, ağırlık, hacim, değer, doku;

3. Psikolojik malzeme: görsel algı ve optik illüzyon sorunları, izleyicilerin içgüdüleri, sezgileri ve duyguları ile tasarımcının kendi ihtiyaçları (Rand, 2014: 26).

Buradan yola çıkarak bir tasarımda biçimsel özellikler önemli olduğu kadar, algıyı yönlendirecek psikolojik etkiler ve yönlendirme şekli de bir o kadar önemlidir.

\section{Tasarımda Pozitif ve Negatif Alan}

Pozitif alan biçimlerin oluşturduğu yüzeylerdir. Biçimler haricinde oluşan alan ise negatif alan olarak anılır. Negatif alan aynı zamanda beyaz alan olarak ya da doluluk - boşluk olarak da anılabilir. Negatif alan daima onu tanımlayacak bir pozitif alana intiyaç duyar ve pozitif alan olmadan var olamaz. Tek başına bir anlam taşıyamaz ve sadece hiçlikten ibarettir. Negatif alanı tanımlayacak olan pozitif alanın varlığıdır. Bu ilişkiden yola çıkarak tasarımda önemli olan ögenin pozitif alan olduğu yanılsamasına düşülmemelidir. Tasarımda algıyı pozitif biçimlerin oluşturduğu alan kadar negatif boşluklar da yönlendirir. Negatif alanın kasıtlı ve bilinçli kullanımı tek başına mesajı taşıyacak ve iletişim kuracak olan bir tasarım prensibi olarak da kullanılabilir. Verilecek mesajın tonunu belirler. Negatif-pozitif ilişkisinde 
bir diğerini değiştirmeden diğerini değiştirmek mümkün değildir. Tamamen birbirlerine bağlı bir ilişki vardır. Figür ve arka plan arasındaki ilişki sayesinde göz bir hareket ve görsel bir aktivite algılar. Görsel tasarımın en önemli elamanlarından biri negatif-pozitif ilişkisidir.Tasarımda arka plan ile figürün arasındaki ilişki arasında çoğunlukla bir mantık bulunur ve birbirini destekler. Burada kurulan mantık kişinin bilgiyi görüntüsel göstergeler yolu ile almasına yardımcı olmaktadır. Dikey veya yukarı açıı bir şekil; dinamizm, hayat, hareket gibi anlamları taşıyabilirken,yatay konumda kullanılan bir çizgi; pasif, zayıf, durağan ve sessiz bir mesaj iletebilir.Negatif-pozitif ilişkisinin algı üzerindeki farklı etkilerini de inceleyen Gestalt kuramı sayesinde bazı durumlarda pozitif ve negatif arasındaki ilişkininkompleks bir hal alabildiği ve görev tanımlarında yer değiştirdikleri görülmektedir. Bazı durumlarda negatif olan aslında pozitif olabilir veya iki pozitif alan olarak da tasarlanabilir.

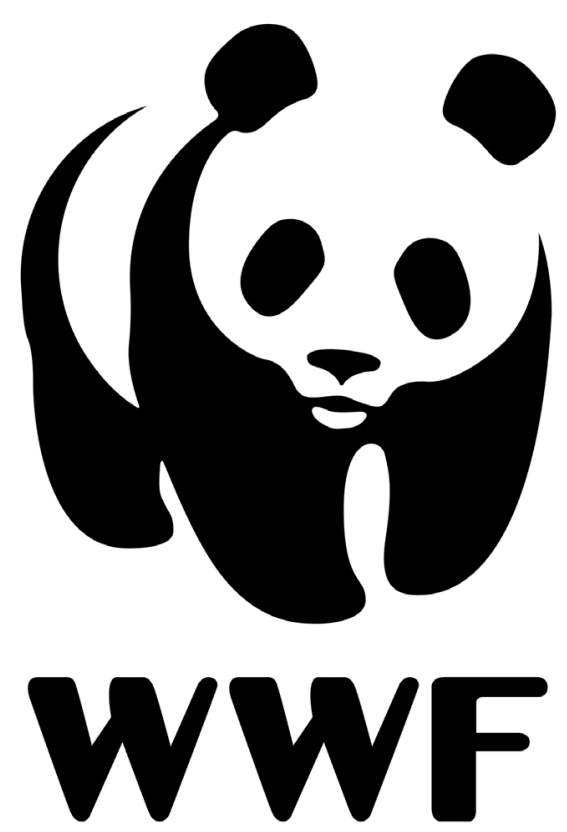

Görsel I. WWF (World Wild Foundation) Logosu.

Gestalt kuramındaki kapalılık ilkesine bir örnek niteliğinde olan World Wild Fund (WWF) organizasyonunun logosunda siyah pozitif lekelerden oluşmuş biçimler vardır. Fakat bu biçimlerin stratejik bir şekilde konumlanması, diğer biçimler arasındaki büyüklük - küçüklük ilişkisi ve orantısı sebebiyle biçimlerin arasında oluşan negatif alan sayesinde bu lekeler bir panda şekli oluşmaktadır. Bu durumda negatif alan olarak kullanılmış beyaz alan da pozitif hale gelmiştir. Doluluk-boşluk ilişkisi kullanılarak bir biçim elde edilmiştir (Görsel 1). Bakan kişi, şekle birkaç saniyeden fazla bakmalıdır ki gözü kompozisyonun tamamını görebilsin ve optik oyunun farkına varabilsin. Doluluk-boşluk ilişkisi aynı zamanda tasarımda boyut ve derinlik katmak amacıyla da kullanılabilmektedir.

\section{Tasarımda Nokta - Çizgi - Kütle}

Nokta: Grafik tasarımın en basit ve yalın elemanı noktadır ve sayfada çapa görevi görür ve dikkati o bölgeyeçeker. Nokta sadece dairesel bir form olmak zorunda değildir; aynı zamanda kare, üçgen, yamuk veya organik bir damla formu da nokta görevi görebilmektedir (Samara, 2007:40). Tasarımda noktanın vereceği etkiyi benzer formda bir görsel kullanımı ile de almak mümkündür vebir tasarım elemanı olarak bakıldığındabu görsel de bir nokta görevi görür. Sayfanın ortasında konumlanmıs bir nokta statik ve durağandır. Odağı toplar ve dominant bir yapıdadır. Sayfanın tam kenarına yerleştirilmiş bir nokta ise bir gerilim yaratabilir ve bir destek noktası olarak çalışabilir.

Çizgi: Çizgisel elemanların temel amacı birleştirmektir. Çizgiler bir kompozisyonda belli biçim ve parçaları birbirine birleştirir. Bu birleşim görünmez de olabilir. Sayfa düzenini tasarlarken kullanılan çizgisel ızgara sistemi sayfadaki farklı elemanları birbirine bağlar. Çizgisel elemanlar sadece ızgara sistem için değil aynı zamanda bir grafik eleman olarak da kullanılabilir, çizgiler hareket ve yön hissi uyandırırlar, statik değil dinamik yapılardır. Bir nokta konum belirtirken çizgiler hareketi ve dinamizmi yansıtır. Dikkati belli bir yere çekmek için çizgilerden faydalanır. Durağanlıktan uzak, hareket halinde bir düzlemdir. Çizgiler alanları birbirinden ayırabilir veya bağlayıcı, birleştirici olarak kullanılabilmektedir (Samara, 2007:44).

Kütle: Bir tasarımda, sayfada farklı aktif ve pasif alanlar oluşturmak için şekillerden destek alınır. Bu gözü bir düzlemin farklı alanlarına yönlendirecek, pozitif ve negatif alanı oluşturacaktır. "Wassily Kandinsky, sarı üçgenin aktif ve dinamik bir form, mavi dairenin soğuk ve pasif olduğuna inanıyordu" (Ambrose ve Harris, 2009:121). Buradan yola çıarak bir tasarımda renklerin etkisi kadar farklı kütle biçimlerinin de belli duygu durumları yarattığı sonucuna varılabilmektedir. Dolayısıyla kütleleri aynı zamanda içerikle ilişkilendirilecek görsel birer metafor olarak kullanmak da mümkündür. "ilyi tasarlanmış bir iletişim için en iyisi, anlam anlayışını en temel düzeyde başlatmaktır" (Samara, 2007:48). Samara da Kandinsky'nin söylediği gibi, soyut formların anlam taşımakta olduğundan bahseder. Çünkü birbirlerinden fark edilebilir şekilde farkııırlar; kütleler anlamını etkileyecek genel bir bağlam ve bir referans çerçevesi oluşturur. Bu sebeple bir tasarımcının 
istediği mesajı iletebilmesi için kompozisyonu stratejik olarak geliştirmesi gerekmektedir. Tasarımcının bu düzeyde aldığı her türlü karar doğru duygu veya ilişkilendirmeyi çağrıştırmalıdır.

\section{Tasarımda Renk}

"Grafik tasarım görsel bir iletişim sanatıdır. Birinci işlevi ise bir mesaj iletmek ya da bir ürün ya da hizmeti tanıtmaktır." (Becer, 2015:33).Becer'in bu sözünden yola çıkarak mesaj iletmek için kullanılan iletişim araçları arasında rengin tasarım elemanları arasındaçok güçlü birgörsel uyaran olduğu ve çok etkili bir iletişim aracı olduğu görülmektedir. Rengin, gözlerin beyne yansıttığı ısık dalgaları olarak değerlendirilmesi nesnel bir tanım olsa da renkler ve aktardığı anlamlar özneldir. Batı toplumlarında yas renginin siyah, Asya'da beyaz olması gibi bir renge kolektif bilinçten, kültürel farklılıklardan etkilenerek farklı coğrafyalarda farklı anlamlar yüklenebilmektedir.Rengin görecelidir ve etrafındaki onuş aran renklere göre değişkenlik gösterebilir. Bu olguya simultane kontrast denir. Kırmızının yanına yerleştirilen yeşil, iki rengi de daha baskın hale getirecektir ama kırmızının yakın tonları arasında yeşil ile birlikte olduğu kadar kuvvetli bir etkisi olmayacaktır (Arnston, 2011:136). Renk psikolojisine bakıldığı zaman da bu görecelilik kavramının geçerli olduğu görülmektedir. Her rengin yarattığı özel duygular vardır bunlar bazen öznelken bazen de evrensel duygu durumlarıdır. Özet olarak sıcak renklerin insanları uyardığı ve soğuk renklerin de sakinlik ve rahatlık verdiği söylenmektedir. Bankaların çoğunlukla güven, otorite, sağlamlık, dürüstlük gibi yansımaları olduğu için lacivert ve koyu mavi tonlarını seçtiği bilinir. Bunun yanında taksiler dikkat çekmek ve diğer araçların arasında fark edilmek için birçok kültürde sarıdır. Doğa ile ilişkilendirilen ürünler için genellikle yeşil skalasından renkler seçilirken, hazır yiyecek (Fastfood) zincirlerinin kurumsal kimlikleri de incelendiğinde iştahı arttıracak uyaran renkler olan kırmızı, sarı turuncu gibi sıcak renklerin tercih edildiği görülmektedir. Bu sebeple bir tasarımcı da daima hedef kitlesinin göz önünde bulundurarak, yaratmak istediği konsepte uygun renk seçimini yapmalıdır?.

\section{Sınıf Temel Grafik Eğitimi: Tasarım Elemanları ile ‘Soyuttan Somuta Kavramlar' Projesi}

Hacettepe Üniversitesi Güzel Sanatlar Fakültesi Grafik Bölümü'nde ikinci sınıf öğrencilerinin aldığı Temel Grafik Eğitimi I ve II derslerinde tasarım elemanlarının ve tasarımın temel ilkelerinin kavranması ve uygulama pratiği

${ }_{7}$ Renk ve tasarımda renk kullanımı ile ilgili detaylı bilgi için bkz. Opara, E. ve Cantwell, J. (2013). Color Works-Best PracticesforGraphic Designer. Beverly, MA: RockportPublishers. için verilen 'Kavramlar' isimli bir proje yürütülmüstür. Bu proje kapsamında; biçim, alan, kompozisyon, şekil-yüzey, negatif-pozitif ilişkisi ve renk üzerine çalışmalar yapılmaktadır. Kontrast, hiyerarşi, uyum, ritim, hareket, birlik, oran-orantı vb. gibi tasarımın temel ilkeleri incelenmekte ve bu ilkelerin proje kapsamında pratik yaparak öğrenme deneyimi sağlanması amaçlanmaktadır. Bu makale 2019-2020 Güz ve Bahar dönemi Temel Grafik Eğitimi I ve II öğrencilerinin 'Kavramlar I ve II' projesi kapsamında ürettikleri işlerinden örnekler içermektedir. Öğrencilerin çalışmaları;biçim, şekil, renk ve kompozisyon yönünden incelenerek anlattıkları kavramlar bağlamında örnekler üzerinden açıklanarak ele alınmıştır.

'Kavramlar' projesi iki aşamadan oluşmaktadır. Birinci aşaması Temel Grafik Eğitimi I dersinin ilk projesi olarak Güz döneminde verilmiştir. İkinci aşama ise Bahar döneminde devam dersi olan Temel Grafik Eğitimi II dersi kapsamında yürütülmüştür. Projenin iki aşaması arasında bir dönem bırakılması, öğrencinin o aralığı başka projeler ile değerlendirmesine ve grafik tasarımın temel ilke ve elemanlarının derinlemesine irdeleyecekleri başka projeler ile pekiştirmesine olanak tanımıştır. Araya başka pekiştirici projeler alınması sayesinde ve 'Kavramlar' projesinin çok basamaklı ve uzun soluklu bir proje olmasından ötürü öğrencinin projeye karşı olan ilgisinin ve şevkinin azalmaması hedeflenmiştir. Meredith Davis, Grafik Tasarımcının Eğitimi adlı kitap çalışmasında öğrencilerin kendi yollarını bulmayı teşvik etmek gerekliliğini ve öğrencilere kendi seslerini geliştirmeleri için fırsat verilmesi gerektiğinden bahsetmektedir (Heller, 2015:77). Kenneth Hiebert ise "kendi kendine yüzleşmeyi teşvik etmek: bireysel bir bakış açısı ve bağımsız yargı geliștirme" nin önemini vurgulamaktadır (Heller, 2015:61). Bu sebeple, öğrencinin bir süre sonra dönemin ilk projesine dönmesi, varsa hatalarını görmek ve aldığı eğitim sonucunda doğru çıkarımla öz eleştiri yapabilmesi ve algısını geliştirebilmesi açısından önem taşımaktadır

Proje kapsamındaki hedeflerden biri öğrenciye araştırma becerisi kazandırmaktır. Frank Baseman, öğrencilerin bir tasarım sürecine girmeden önce konu ile ilgili uzun ve detaylı bir düşünme ve yazma süreci geçirmeleri gerektiğinden bahseder. Eğitmenlerin de bu beyin fırtınası, konsept çalışması ve arastırma sürecini teşvik etmeleri gerektiğini vurgulamaktadır (Heller 2015:20). Bu sebeple öğrencinin grafik tasarım konuları haricinde de bir araştırma sürdürmesi planlanmıştır. Öğrencilerden bir müzisyen seçmesi istenmiştir ve öğrenciler seçtikleri müzisyenler hakkında bir ön araştırma yapmış ve eserlerini dinlemiştir. Öğrencilerden seçilen bestecinin 5 farklı eserinin seçilmesi ve bu seçtikleri eserleri dinleyerek duygu analizi yapmaları istenmiştir. Bu süreçte öğrenciye her hangi bir yönlendirme yapılmamıştır. Davis, öğrencilerin mümkün oldukça kendi konularını kendilerinin 
seçmesinin kendi yollarını bulmadaki olumlu etkisinden bahsetmektedir (Heller,2015:77).

Projenin amaçlarından bir diğeri de soyut düşünme pratiği yaptırmak ve soyut kavramların grafik elemanların kullanımı ile somutlaştıııması ve görsel bir anlatım dili oluşturulmasıdır. Bauhaus'un Temel Tasarım dersinde tasarım eğitimi, öğrenciler belirli intiyaçlara ve mecralar için uygulanan tasarım problemlerini çözmeye başlamadan öncee vrensel tasarım prensiplerini tanıtmak için soyut problemlerle baslatılmışır (Heller, 2015:5). Soyutlama ve deneysellik Bauhaus ekolü ile birlikte tasarım eğitiminin önemli bir kısmını oluşturmaktadır. Bauhaus okulu tasarım elemanları ve prensiplerine yapmış olduğu vurgu ile grafik tasarımı kökünden etkilemiştir. 'Biçim işlevi izler' sözünden yola çıkarak, bir nesnenin biçiminin, nesnenin hakkında bilgi verecek nitelikte islevine uygun olması gerektiği düsturunu benimsemiștir (Arnston, 2011:213).Buradan yola çıkılarak, soyut kavramların seçiminde öğrencilerden yaptıkları duygu analizi sonucu 5 farklı beste için 5 farkIı olumlu veya olumsuz duygu durumu (Heyecan, dehşet, sevinç, keder, umut, baskı vb. gibi) belirlenmesi beklenmiştir. Seçilen duygu durumları ve soyut kavramlar yapılan sınıf içi tartışma ve beyin fırtınasında irdelenmiş, somutlaştırma aşamasına ve tasarıma geçmeden önce yapılarına ayrılmıştır. Öğrencilerden kendilerine "Bu soyut kavram bir kütle olsayd nasıl bir biçim alırdı?" sorusunu sormaları istenmiştir. Örneğin öfke kavramı için; sert, sivri köşeli, büyük, koyu, kütlesel, baskın gibi çıkarımlara varılmış̧ır. Öğrencilerden tasarımlarına baslamadan önce kavramlarını tek tek düşünmeleri ve somut yapısal özelliklerine karar vermeleri istenmiştir. Bu yapısal özellikler sayfa düzenlerinde; çizgi/nokta, açı/kıvrım, düz/ dokulu, düzlemsel/hacimli, aydınlık/karanlık, ince/kalın, geometrik/organik, sert/yumuşak, opak/saydam, büyük/küçük, gruplu/ayrı, aktif/pasif, basit/karmaşık, dikey/yatay, bitişik/üst üste, simetrik/asimetrik, düzenli/ düzensiz gibi hangi elemanları kullanacaklarına karar vermede kolaylaştırıcı olmuştur. illk basamakta oluşturulan kavramın yapısal özellikleri listesine sadık kalınarak eskiz çalışmasına başlanmışırı ve temel tasarım ilkeleri de göz önünde bulundurularak kompozisyon çalışmasına başlanmıştır. Bu aşamada verilen kritikler doğrultusunda öğrenciler hem farklı kompozisyonlar ve sayfa düzenleri denemiş hem de temel ilkeleri öğrenme ve pekiştirme şansı elde etmiştir. Projenin bu ilk basamağında sadece siyah/beyaz çalıșılmış, renklerin desteği olmadan sadece biçim ve alan üzerinden kurulacak olan algı iletişimine önem verilmiştir.

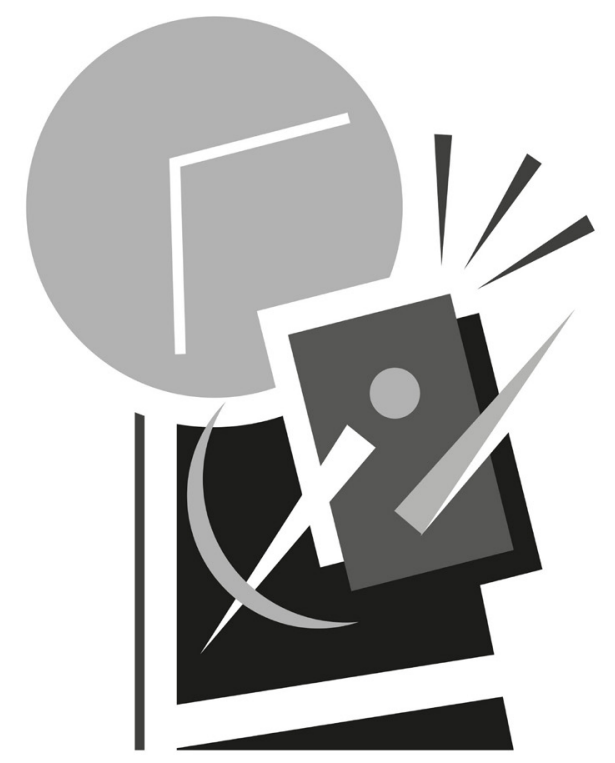

Görsel 2. Demet Özkan, Kavram: İsyan, 2019. (Örnek öğrenci projesi).

Örneğin, Görsel 2'deki isyan kavramı için siyah beyaz olarak tasarlanmış olan kompozisyonda öğrenci karşı çıkmak ve ayrışmak temalarından yola çıkmıstır. Bu sebeple kullanacağı biçimlerin yapısal özellikleri olarak sivri ve sert hatlı köşeler ve kütlesel yoğun lekeleri tercih etmiştir. Kompozisyonda sağa yukarı doğru hareketli olan dinamik dikey yapı isyan duygusunu, ayrışmayı ve karşı çıkmayı somutlaştırma aşamasında destekleyici unsur olmuştur.

Projenin birinci aşaması temel olarak soyut-somut ilişkisi üzerine kurulmuştur. Soyut olanı somut bir biçim olarak düşünme yetisini kazandırmak amaçlanmıştır. Bu noktada öğrencilerin duygu durumları gibi soyut kavramları izleyiciye biçimler aracılığı ile hissettirecek görsel algıyı oturtmaları projenin en temel basamağını oluşturmuştur. Somut bir varlığın yardımı olmadan tasarlamanın yaratıcılı̆̆ı pekiştirmesi hedeflenmiştir.

Projenin ikinci basamağına devam dersi olan Temel Grafik Eğitimi Il dersinde bahar döneminde devam edilmiştir. Aynı kompozisyonların renklendirilmesi ve bu kompozisyonlardan bir afis üretmek projenin ikinci așamasını oluşturmaktadır. Öncelikli olarak tasarımda renk psikolojisi ve kullanımı konusu 
örnekler üzerinden işlenmiştir. Sınıf içi alı̧̧ırıma olarak da her öğrencinin bir grafik ürün seçmesi ve bu ürünün renk paletini çıkarması, renklerin seçilen tasarımda neden önemli olduğu ve ne mesaj taşıdığını araştırması istenmiştir. Bu çalışmalar sınıf ortamında tüm sınıfın katııımı ile tartışmaya açımış, öğrencilerin paylaşımda olması sağlanmıştır. Bu alıștırma sonrasında 5 farklı eser için hazırlanmış siyah beyaz çalışmalar renklendirilme aşamasına geçilmiştir ve birinci aşamada çıkarılan duygu analizi listesi tekrar incelenerek söz konusu duyguları yansıtacak renkler araştıııımışır. Bu noktada ise tasarımda ton, değer, doygunluk, sıcaklık farklılıkları ve bunların etkisi incelenmiş ve tartışılmışı. Renkler kullanılarak seçilmiş olan duygunun/ kavramın anlatıldığı görsel bir hiyerarşik düzen oluşturulmuş, öne çıkması planlanan biçimler bu sayede vurgulanmıştır. Renk uygulaması sırasında, sayfa düzenlemesini ana hiyerarşiyi ve sonraki alt hiyerarşileri gösteren siyah/beyaz kompozisyonlar bir kılavuz görevi görmüştür. Bir tasarımda renk paletini oluştururken öncelikli olarak algının doğru yönlendirilmesi için önce hiyerarşik düzen oluşturulması ve bu sayede güçlü,doğru sıralaması olan bir görsel dil kurgulayarak renk kullanımının tasarımda tamamlayıcı bir eleman olarak kullanması hedeflenmiștir. Öğrencilerin tasarımda renk kontrastını, tonu ve doygunluğu yüzeyde bir boyut değişikliği yaratmaya yardımcı olarak kullanmaları ve bu sayede anlatımlarını daha dramatik ve etkili bir şekilde kuvvetlendirmeleri amaçlanmıştır (Görsel 3).
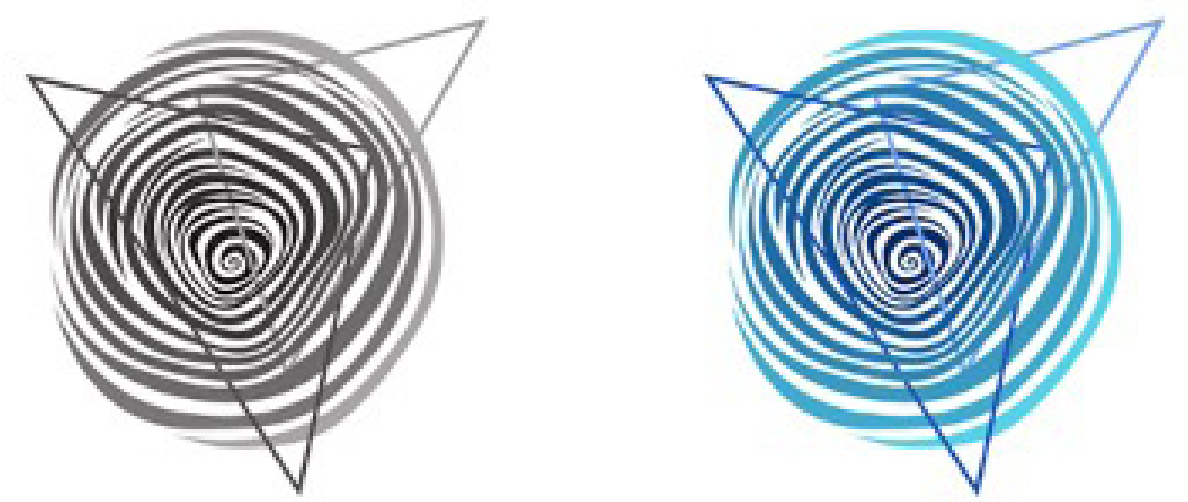

Görsel 3. Selen Saçlık, Kavram: Derinlik, 2020. (Örnek öğrenci projesi).
Rengin bilinçli kullanılması, tasarımda algılanan formun derinliğini değiştirebildiği gibi farklı düzlemsel konumlarda yerleşimi ile birlikte görsel hiyerarşi oluşturarak her bir formun önem sıralaması üzerinde büyük bir etkiye sahip olabilir. Projenin ikinci aşamasında yapılan renk çalışmasında, her form ön plan, sonra orta zemin ve daha sonra bileşimin arka plan düşünülerek, farklı renk kombinasyonları ile deneme yapılarak farklı kaydedilir. Arka plan rengi de değişimine katıldığında elde edilen etki derinlik ve boyut açısından daha da dramatik hale gelir.Sonuç olarak farklı renk kombinasyonları ile farklı düzlemsel derinlikleri olan konumlar elde edilmektedir (Görsel 4).


Görsel 4. Beyza Çelikbaş, Kavram: Bütünlük, 2020. (Örnek öğrenci projesi). 
Bütünlük kavramı için tasarlanmış olan bu çalışmada 'farklı düşüncelerin, yapıların birliği' kavramı üzerinde durulmuştur. Kompozisyon kurgulanırken, farklı formlar arasında bir birlik kurulması hedeflenmiştir. Kullanılan formlardan bazısı boşlukta bir derinlik algısı uyandırırken, bazısı daha agresif bir çeşit gerginlik yaratırken, bazıları kıvrımlı yapısı sebebi ile daha az gerginlik sunar. Aynı zamanda, açılı ve köşeli düzlemler, kıvrımlı yapılar ve çizgiler ile birbiriyle kontrast oluşturur. Farklı formların oluşturduğu birlik başka türlü bir gerilim türüdür. Görünür bir mekânsal konumda olmaları bir derinlik ve uzay algısı yaratırken, birbirlerinin keskin, geometrik niteliklerini de tamamlarlar(Görsel 4).

Projenin son aşamasında ise revize edilmiş ve renklendirilmiş ilk kompozisyonlar söz konusu eser sahibi için tasarlanmış bir müzik afiş̧ çalışmasınadönüstürülmüstür. Bu noktaya kadar olan süreçte öğrenci tasarımında kendi seçmiş olduğu duyguyu anlatacak görsel dengeyi kurmuş ve bunu renk ile pekiştirmiştir. Fakat çalışmalar bu aşamada henüz bir grafik ürün değildir.Bu sebeple projenin son basamağında bu çalışmaların bir afiş haline getirilmesi beklenmektedir. Bu aşamada afişte yaratılmak istenen etkiyi destekleyen bir tipografi eklemesi ile tipografinin de bir grafik eleman olarak kullanılması, leke olarak sayfa düzenine etkisi, vurgusunun araştırılması ve deneyimlenmesi hedeflenmiştir. Güler Ertan ve Emin Sansarcı'ya göre bir tasarımcının birincil görevi tasarladığı afişin diğer rakipleri arasında fark edilmesini sağlamaktır (2016:164) ve bir afiş tasarlarken tasarımcının cevabını bulması gereken sorular vardır:

"Yapılan afişte neye ulaşmak istiyorsunuz?

Afişin amacı nedir?

Afişte vurguladığımız mesaj kimleri hedefliyor?

\section{Hedef kitleniz kimdir?}

Yaptı̆̆ımız afiş ulusal mı yoksa uluslararası bir kitleye mi hitap ediyor?

Hedef kitlenin ortak özellikleri var mı?

Afişte tanıtılacak şey bir ürün mü, hizmet mi yoksa bir düşünce ya da felsefe mi?" (Güler ve Sansarcı, 2016:165).

Buradan yola çıkarak öğrencilerden de kendilerine bu soruları sormaları ve uygun olduğunu düşündükleri yanıtları vermeleri beklenmiştir. Bu noktada öğrenci ilk aşamalarda kullanmış olduğu grafik elemanların yerini tutabilecek görseller kullanmakta da özgürdür. "Bir kelimenin nasıl kullanıldığı ve yerleştirildiği, kelimenin anlamı kadar iletişim kurar. Farklı yazı tiplerinin farklı "kişilikleri" vardır ve buna göre farklı anlamlar taşır (Ambrose ve Harris, 2009: 108). Bu aşamada öğrenci tipografiyi de bir tasarım eleman olarak kullanmayı pratik edecektir ve mesajın destekleyecek seçimlerde bulunması beklenmektedir. Lekesel değerlerle çalışılmış kompozisyonla artık fotoğraf ve tipografi de içeren fakat, denge, ağırlık, kontrast ve genel etkisi açısından değişmemiş bir grafik ürün olarak ele alınmıştır ve bir afiş haline getirilmiştir ${ }^{8}$ (Görsel 5).

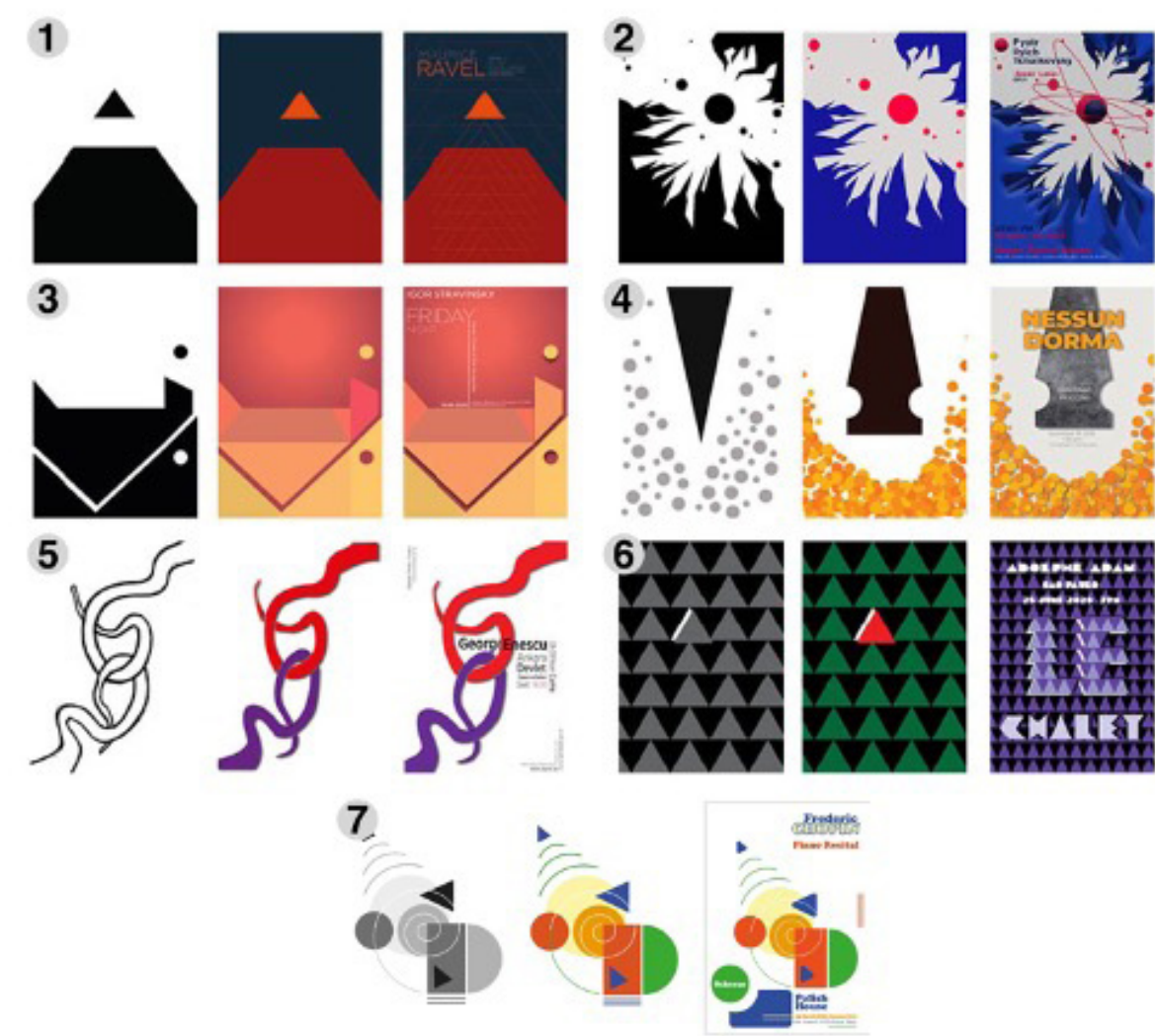

Görsel 5. Sırasıyla; I- Beyza Çelikbaş, Kavram: Hedef, 2- Beril Dinçer, Kavram: Çatışma, 3- Tekin Sefa Kızılkaya, Kavram: Tamamlanma, 4- Selen Saçılık, Kavram: Baskı, 5

Demet Aytemir, Kavram: Bağlılık, 6- Mustafa Aracı, Kavram: Huzursuzluk, 7- Demet Özkan, Kavram: Eğlence.(Örnek öğrenci proje seçkisi).

Grafik tasarımda tipografinin tasarım elemanı olarak kullanımı ve detayı bilgi için bkz. Ambrose, G., \& Harris, P. (2006). Thefundamentals of typography. Ava Publishing. 
Tasarım odaklı düşünme ve yaratıcı düşünme tekniklerinin ortak noktası beyin fırtınası ve grup içinde kolektif düşünme tasarım sürecindeki en önemli basamaklardan biridir. Beyin fırtınası süreci, öncelikle ele alınacak problemi tanımlayarakve yaratıcı süreci harekete geçirecek sorular oluşturarak başlar (Ambrose ve Harris, 2009:66) ${ }^{9}$. Eğitmen tarafından ders kapsamında sınıf içi tartışma ortamları yaratılarak beyin fırtınası seansları ve toplu kritikler ile öğrencilerin sınıf içinde birbirlerinin çalışmalarını görüp yorumları dinleyerek katkıda ve eleştiride bulunmaları desteklenmelidir. Bu sayede öğrencinin hem akranlarından hem de eğitmeninden bilgi alışverişinde bulunacağı çok yönlü bir öğrenim ağı kurulabilir. Bu noktada eğitmenin öğrenciler ile kuracağı güçlü diyalog da öğrenme ve eleştirel düşünme becerilerini pekiştirir. "Etkili öğrenme bütün bileşenlerin öğretmenin bir orkestra şefi gibi doğru yönetmesiyle harmonik bir hal almaktadır" (Pehlivan Baskın, 2018:73).Proje kapsamında her hafta yapılan toplu ara kritiklere tüm öğrencilerin katılımı şart koyulmuştur. Öğrencilerin öğrenme süreçlerine katkıda bulunacak şekilde fikir alışverişi yapmaları ve yorum yapmaları zorunlu kılınmışır. Böylece projenin başlangıcı ve bitişi arasında her hafta düzenli olarak ara kritikler verilmiş tüm sınıfın bu sürece katılıp akran destekli öğrenim ortamı oluşturulması hedeflenmiş̧tir. Proje, teslim günü öğrencilerden projelerini sınıf önünde sunmaları ve çalışmalarını açıklamaları ile sonlandırılmıştır. Bu aşamada öğrencinin sunum becerilerini pekiştirmesi hedeflenmiştir. Tasarım çözümlerinin her zaman bir müşteriye anlatılması gereklidir ve bu aşamada iyi bir sunum yapılarak fikirlerin doğru bir yolla karşı tarafa aktarılması önemlidir. "Kötü bir şekilde sunulan iyi bir fikir ilk engelde başarısız olacaktır" (Ambrose ve Harris, 2009:80).

\section{Sonuç}

Tasarım bir problem çözme sanatıdır. Tasarımcı elindeki verileri basit parçalara ayırdığında çözmeye çalıştığı problematiği daha iyi ve daha net bir şekilde ifade edebilir. Bir tasarımda görsel algının inşası tasarımcı tarafından yapılmaktadır ve tasarımcının izleyicinin algısını yönlendirme kudreti vardır ve bu gücünü bilinçli kullanmalıdır. Bir tasarımcının yaratıcı ve eleştirel bir bakış açııının olması çok önem taşımaktadır fakat bu tek başına yeterli de değildir. Aynı zamanda gerekli formülleri kullanarak algıyı ve bilinci yönlendirecek kilit kararlar da alabilmesi gereklidir. Görsel algının doğru inşasını kurmak için ise bir öğrencinin tasarımın temel kural ve prensiplerini öğrenmesi ve formülleri yerinde kullanması algıyı doğru kurgulamayı öğrenmesi eğitiminin önemli bir kısmını oluşturmaktadır. Her tasarımın veya görüntünün özünde bir kavram, düşünce veya bir mesaj vardır.

${ }_{9}^{9}$ Beyin firtınası sırasında izlenecek kurallar ve detaylı bilgi için bkz. Ambrose, G., \& Harris, P. (2009). Basics design 08: designthinking. Bloomsbury Publishing.
Şeklin algılanmasının kavramı oluşturmanın başlangıcı olarak kabul edilirse, bir şekle yüklenen yapısal özelliklerin doğru kavranmasıyla birlikte anlama da başlamış olur ve mesaj transferi gerçekleşir. Başarılı çözümlenmiş kompozisyonlar net ve anlaşlabilir görsel mesajlar iletir. Bir kompozisyonun iyi çözümlenmiş veya işlenmiş olması, hangi biçimin hangi mesajı vermek istediği ve bunun zemin ile genel ilişkisinin toplam etkisi konusunda bilinçli kararlar verilmiş olmasına bağlıdır. Çözümlenmiş bir kompozisyonda biçimlerin boyutu, konumu, rengi, tipografisi birbirleri ve çevresindeki boşluk ile ilişkisi bilinçli bir şekilde ayarlanmalıdır. Mesajı karşı tarafa iletmek için her biçimin bir anlamı ve tanımı ve kullanım amacı vardır. İşlev düşünülmeksizin sadece biçim üzerinde yoğunlaşan tanımsız şekil ve formlar grafik tasarımın görsel mesajlar vasıtasıyla iletişim kurma özelliğini zayıflatacaktır. Temel tasarım elemanlarının ve prensiplerinin özümsenmesi ve pratiğe dökülmesi, tipografi ve görsellerin grafik eleman olarak kullanımı, doğru iletişim için önem sırasına göre görsel bir hiyerarşik düzen kurulmasının öneminin vurgulanması ancak grafik tasarım eğitimi sayesinde mümkündür. Öğrencilerin tasarım odaklı düşünme süreci, yaratıcı ve eleştirel bir bakış kazanmasıyla beraber temel tasarım elemanlarını kullanmayı öğrenmesi sonrasında iyi birer tasarımcı olma yolunda atacakları önemli bir adımdır. Bu makalede, Hacettepe Üniversitesi Güzel Sanatlar Fakültesi Grafik Bölümü 2.Sınıf Temel Grafik Eğitimi Stüdyosu'nda yürütülen temel tasarım elemanları ile görsel algı oluşturma projesi,proje süresince varılması hedeflenen ve amaçlanan noktalar belirtilmiş, öğrenci işleri üzerinden örneklendirilerek açıklanmıştır. 


\section{Kaynakça}

Ambrose, G. ve Harris, P. (2009). Basics design 08: design thinking. Bloomsbury Publishing.

Arnheim, R.(2009). Görsel düşünme (çev. R. Öğdül). Metis Yayınları.

Arntson, A. E. (20I I). Graphic design basics. Cengage Learning.

Becer, E. (20।5). İletişim ve grafik tasarım. Dost Kitabevi Yayınları.

Bektas, D. (1992). Çağas, grafik tasarımın gelişimi. Istanbul: Yapı Kredi Yayıncılık.

Ellis, W. D. (Editör). (1950).A Source Book of Gestalt Psychology.

Ertan, G. veSansarcı, E. (20I7). Görsel sanatlarda anlam ve algı. İstanbul: Alternatif Yayıncilık.

Findeli, A. (200I). Rethinking design education for the 2Ist century: Theoretical, methodological, and ethical discussion. Design issues, I7(1), 5- I7.

Güz, N., Huber, E., Senemoğlu, O. ve Öztokat, E. (2002). Açılamalı Dilbilim Terimleri Sözlğü. (Editör: Berke Vardar). İstanbul: Multilingual.

Heller, S. (20I5). The education of a graphic designer. Simon and Schuster.

Meggs, P. B. ve Purvis, A. W. (20 2). Meggs' history of graphic design (5.Baskı). Hoboken, NJ: J. Wiley \& Sons.

Pehlivan Baskın, Z. (2018). Zenginleştirilmiş Görsellerin Kullanılmasının Sanat Tarih Eğitimine Katkısının Saptanması. Sanat ve Tasarım Dergisi 59-74 . DOI:10.18603/ sanatvetasarim. 435640

Rand, P. (20I4). Thoughts on design. Chronicle Books.

Samara, T. (2007). Design elements: A graphicstylemanual. Rockportpublishers. Theoretical, methodological, and ethical discussion. Design issues, I7(I), 5-I7.

Uçar, T. F., Orhon, N., Taş̧̧ıoğlu, M. ve Kılıç, L. (20I3). Görsel kültür. Eskişehir: TC

Anadolu Üniversitesi Yayını.
Wingler, H. M. (1979). The Bauhaus. Cambridge: MIT Press.

\section{İnternet Kaynakları}

Internet: Bennett, A. G. (20I I). Icograda design education manifesto 20I I, 8-9. Web: https://www.ico-d.org/database/files/library/

IcogradaEducationManifesto_20 I I.pdf adresinden 0I Nisan 202 I tarihinde alınmıştır

\section{Görsel Kaynaklar}

Görsel I. WWF Logosu. https://wwf.panda.org/discover/knowledge_hub/ history/?\#: : text =What\%20is\%20the\%20story\%20behind\%20the\%20 panda\%20logo\%20of\%20WWF\%3F\&text=The\%20inspiration\%20came\%20 from\%20Chi,years\%20before\%20WWF\%20was\%20created.

Görsel 2. Demet Özkan, Kavram: İsyan, 2019. (Örnek öğrenci projesi). Kişisel Arşiv.

Görsel 3. Selen Saçlık,Kavram: Derinlik, 2020. (Örnek öğrenci projesi). Kişisel Arşiv.

Görsel 4. Beyza Çelikbaş, Kavram: Bütünlük, 2020. (Örnek öğrenci projesi). Kișisel Arşiv.

Görsel 5. Sırasıyla; I- Beyza Çelikbaş, Kavram: Hedef, 2- Beril Dinçer, Kavram: Çatışma, 3- Tekin Sefa Kızılkaya, Kavram: Tamamlanma, 4- Selen Saçılık, Kavram: Baskı, 5- Demet Aytemir, Kavram: Bağılık, 6- Mustafa Aracı, Kavram: Huzursuzluk, 7Demet Özkan, Kavram: Eğlence.(Örnek öğrenci proje seçkisi). Kişisel Arşiv. 